\title{
TEACHING ENGLISH THROUGH YOUTUBE: GRAMMAR VIDEO ANALYSIS OF THREE BRAZILIAN YOUTUBE CHANNELS DEDICATED TO EFL TEACHING
}

\author{
Aline Fay de Azevedo \\ School of Humanities, Pontifical Catholic University of Rio Grande do Sul, Rio Grande do Sul, Brazil \\ E-mail: aline.azevedo@pucrs.br \\ Juliana Matias \\ School of Humanities, Pontifical Catholic University of Rio Grande do Sul, Rio Grande do Sul, Brazil \\ E-mail: juliana.matias@acad.pucrs.br
}

\begin{abstract}
APA Citation: Fay, A. A., \& Matias, J. (2019). Teaching English through YouTube: Grammar video analysis of three Brazilian YouTube channels dedicated to EFL teaching. English Review: Journal of English Education, 8(1), 1-10. doi: 10.25134/erjee.v8i1.2351.
\end{abstract}

Abstract: The objective of this research is to analyze grammar lessons of three Brazilian YouTube Channels of English as a Foreign Language. It compares the approaches applied by each teacher in their videos and investigates if the lessons approach the explanation of meaning, use, and form of the grammar. It also aims to find out if the lessons are hackneyed regarding the online learning environment. The analysis consisted of watching two videos of the YouTube channels English in Brazil, Inglês Compartilhado and Mairo Vergara. The results showed that out of the six videos, five contained a grammar explanation that addressed meaning, use, and form of the language. They also adopted the deductive approach to grammar teaching. Only one video did not explain the grammar (quantifiers), but a trick to memorize the use of quantifiers. As for technology, the main tool teachers used was captions to illustrate example sentences of the grammar. Other tools consisted of the use of the software 'Notepad' and animation. Thus, there was not an innovation on the videos regarding technology. Future research is needed to understand if there is the necessity to apply cutting-edge tools to teach on YouTube and if it is mandatory to review and to adapt the pedagogical practices for language learning YouTube videos.

Keywords: English grammar; videos; YouTubers; technology; deductive approach.

\section{INTRODUCTION}

The education 3.0 along with technology has provided more tools and opportunities for English language teachers (Gerstein, 2014). The interactive whiteboard, for instance, allows the teacher to save notes and send them to students. There are also official and unofficial blogs dedicated to English Language Teaching with several resources for all levels. Such tools become accessible due to the Computer Assistance Language Learning (Levy, 1997). Besides, CALL has also provided online platforms, such as teacher's personal courses and Moodle to teach English online.

Lately, YouTube has provided minicourses and a guideline for teachers who want to start an education channel or who want to improve their existent one. Thus, it is not a surprise that there is an increasing number of YouTube channels specialized in teaching English to non-native speakers. In Brazil, the number of EFL YouTube channels are up to 38 (YouTube Education Project, 2018). Apparently, students have been using YouTube as a complementary tool of learning English. The platform has also allowed free access to learning, which leads people who cannot afford a regular course to study by watching the videos. However, students may not be able to identify the quality of the lessons and many ask teachers to suggest EFL YouTube channels. Hence, the origins of this paper lie on this issue.

Deductive approach vs. inductive approach

There are two different ways of teaching a given grammar point in English: the deductive and inductive approaches. The former is traditional teaching whereas the latter considers the student as the center of learning. Both approaches have contributed enormously to ELT, but there is still discussion about their application in class since teachers have different point of views about their efficiency. The deductive approach, also addressed as rule-driven learning, consists of presenting a rule, along with showing examples in which the rule is applied and finally, a written exercise practice of that rule (Thornbury, 1999). 
This approach is also recognized as a traditional one since it is teacher-centered and focuses on rules rather than the use of the language. Its use, however, appears to rely on the teacher's personal beliefs and teaching habits. Some may feel more comfortable providing the examples themselves rather than engaging students to observe the rules independently.

Different from the deductive approach, the inductive approach consists of providing examples and inferring rules afterwards. According to Thornbury (1999), the typical inductive approach is: 1) the teacher provides example sentences; 2) the teacher asks the students to identify the grammar, speculate it and come up with hypothesis; 3) the students exchange ideas and show their findings to the class; 4) the teacher explains the grammar briefly and may ask students to reproduce the language providing some keywords; and 5) the students do a controlled-practice exercise.

Not surprisingly, many also call this approach discovery learning since it engages students to find rules themselves before hearing any formal explanation from the teacher.

\section{The three dimensions}

Larsen-Freeman, et al. (2016) suggest that it is important to give attention to the three dimensions: form, meaning and use. According to them, if there is a change in one of the dimensions, then a change in another one happens as well.

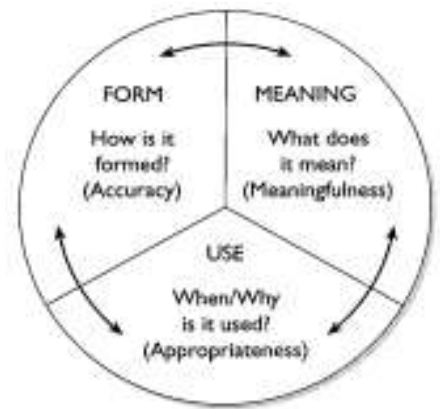

Figure 1. The three-dimensions chart

Form concerns the sequence and constructions of grammar within a sentence. For instance, in a class focusing on the simple past with regular verbs, the teacher might provide the following information to students (not necessarily, using the same words and terminologies): We create regular verbs in the past by adding -ed to the base form. For verbs that end in -e (like), we add $-\mathrm{d}$ (liked). If the verb ends in a consonant $+\mathrm{y}$, we change $y$ to $-\mathrm{i}$ and add -ed (study - studied). We double the consonant and add -ed if it has one syllable and ends in consonant + vowel + consonant (stop - stopped).

Meanwhile, meaning refers to the denotation of a particular grammar construction. As an example of meaning, the teacher could approach time expressions. They inform when an event occurred in the past and might mean a different time. In the sentence "I played soccer yesterday," the time expression yesterday means the previous day. The event in the past can also refer to something that endured for a certain period: "I played soccer for five years." In this sentence, the subject specified the duration of the action by using the time expression for. Since it may be too much information for students, especially beginners, the teacher should analyze which ones are more relevant for the class and teach them with context.

In addition to form and meaning, use is an essential aspect of language that students need to understand. It is curious that even though books for EFL teachers provide information about the use of a grammar aspect, grammar-teaching researches do not mention it (Parrot, 2010; Scrivener, 2010). On the other hand, LarsenFreeman (1991) and Larsen-Freeman et al. (2016) discuss this issue. Thus, use approaches the way such a construction works in a certain context. An example of language use in the simple past the teacher can adopt is emphatic statements (Scrivener, 2010). When the speaker wants to emphasize something that occurred in the past, it is possible to use did + the base form of the verb: "I did keep your secret, I swear!" In this example, the person wants to make sure that the action happened, even though someone says the contrary.

\section{YouTube and education}

The contribution of YouTube to education did not go unnoticed. Oliveira and Viggiano (2018) claim that according to YouTube, $65 \%$ of users access the platform when they want to learn something. Furthermore, educational content is watched $\mathbf{5 0 0}$ million times a day every day and is watched four times longer than cute kitten videos. Not surprisingly, on November 11th, 2013, Google launched YouTube EDU (YTEDU), a special part of the platform exclusive for learning. According to Galastri (2013), YouTube EDU is a complement to the traditional class and its aim is to provide content that students and teachers can use inside and outside the classroom. It contains reliable channels of different school subjects as well as internet safety tips. In Brazil, if a teacher wants to 
be part of YouTube EDU, he/she must fill an application form and professionals of Fundação Lemann, Unicamp and Curso Poliedro will analyze the channel. If it matches their criteria, the channel is included in the platform.

Regarding English teaching, there are numerous studies about the use of YouTube to teach listening and writing (Kelsen, 2009; Mayora, 2009; Silviyanti, 2014; Watkins \& Wilkins, 2013). In addition, the website LyricsTraining (lyricistraining.com) uses music videos from YouTube on its game, which consists of filling the gaps of popular song lyrics. Another website that features YouTube is YouGlish (youglish.com) which dedicates to demonstrate the pronunciation of English words in American, Australian and British accent. Nowadays, educators are also using ted-talks from TED (ted.com) in their classes in order to work with different English skills. In fact, the website also provides a section called TedED (https://ed.ted.com/lessons) in which educators can make lesson plans based on talks and share on the platform.

It seems that most educators see it only as an auxiliary tool to include in the language classroom. Thus, there is little is discussion in the literature about YouTube as a potential tool to teach English. In fact, there is still a lack of studies regarding teaching English on this platform. This may be partially dangerous since anyone could upload a video explaining something about the English language in a wrong way or without providing enough input to make learners understand the content. Thus, apart from YouTube EDU, there is no control about the quality of lessons on the platform. That being said, the present paper intends to provide a little demonstration of what teachers are creating on Brazilian YouTube regarding grammar teaching.

Based on the background previously described, the guiding questions of this paper are:

1. Is there anything ingenious being produced by the Brazilian EFL teachers on YouTube?

2. Which grammar approach(s) do the teachers apply?

3. Do teachers approach form, meaning and use in their lessons? How do they illustrate these three dimensions?

\section{METHOD}

One of the aims of this paper is to analyze three grammar lessons of three (3) Brazilian YouTube Channels: Mairo Vergara, Inglês Compartilhado by Tainá Alves and English in Brazil by Carina Fragozo.

Although YouTube is one of the most accessed types of media and teachers have been using it for educational purposes, it is important to mention that there is little literature dedicated to this phenomenon. Alhamami (2013, p. 4) supports this statement and claims, "language teachers might not find clear guidelines that help them use this technology in their careers."

The analysis will consist of watching the videos carefully and take notes of the lessons' steps according to the evaluation guideline designed by Alhamami (2013). The author made the guideline focusing on YouTube Language Learning Videos (YouTube LLVS), therefore it does not focus on grammar teaching exclusively. Since the objective of this research is to analyze how teacher explain grammar, it adapts the guideline by adding specific questions regarding grammar teaching. That being said, the evaluation guideline will consist of questions that analyze the YouTube videos in general and the grammar content.

\section{RESULTS AND DISCUSSION \\ Videos about quantifiers \\ Much/many/a lot of: aprenda a regra! (Countable/Uncountable nouns) - English in Brazil by Carina Fragozo}

Carina starts the lesson by saying that "much" and "many" have the meaning of "a large amount of something" in many contexts. The fact that she explains it orally gives evidence that the grammar approach is deductive (Thornbury, 1999).

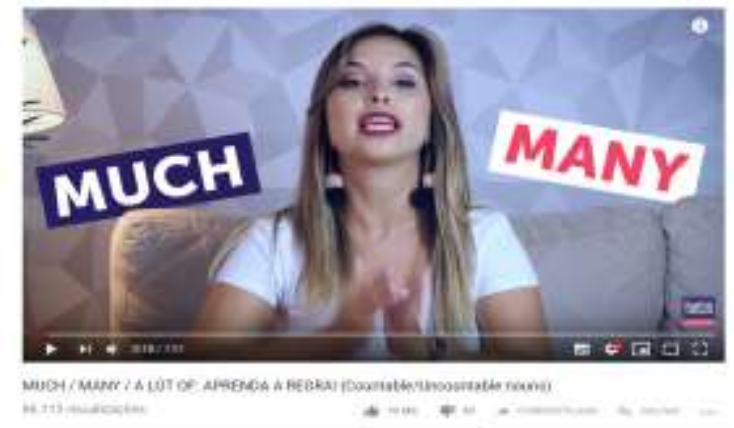

Figure 2. English in Brazil's video about quantifiers

The teacher approaches the form of the quantifiers by saying that "many" goes with countable nouns and "much" goes with uncountable nouns. For "many", she uses the example of apples. A short animation of three apples shaking appear on the video and then, she counts in Brazilian Portuguese and English "One apple, two apples, three apples" and say that they 
are countable and that it is possible to transform the noun "apple" in the plural form. By mentioning that countable nouns have the plural from, she provides important information of the grammar aspect.

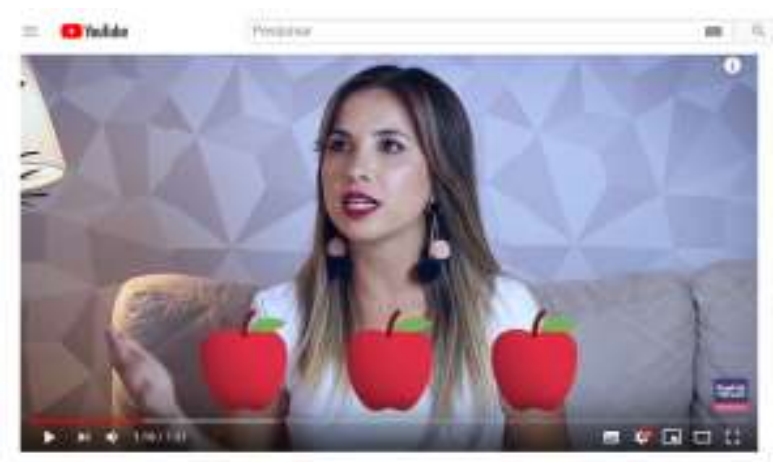

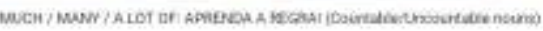

Figure 3. Animation to illustrate that the noun "apple" is countable

Following the explanation of countable nouns, Carina explains that "much" is for uncountable nouns. In other words, nouns that you cannot quantify. She considers "water" as a classical example because similar to Brazilian Portuguese, it is not possible to say, "There are many waters here". She then provides the example "How much water do you drink every day?" that appears in the video in the same colors as the previous examples. The meaning she provides is an explanation in her native language of the sentence. As for the form of questions with uncountable nouns, there is not any explanation. A reason for not approaching the question forms in the video might relate to Larsen-Freeman's (1991) claim that it is not necessary to explain everything in one lesson. The steps of explanation are the same for the sentence "I don't drink much juice" and the teacher says that, according to grammar books, liquids, in general, are uncountable.

Example sentence only for the first one ( I drank too much Coke yesterday). The next example sentences are "Can I have two Cokes?", "Two Cokes, please" and "Two cans of Coke." Again, she provides extra information about the grammar, following the claims of LarsenFreeman et al. (2016) and Larsen-Freeman (1991). After the explanation of "much" and "many", Carina reviews the grammar points by revisiting the examples that appeared before:

a) How much water did you drink?

b) How many bottles of water did you drink?

c) How much money do you have?

d) How many dollars do you have here?
Finally, she introduces another use of quantifier: a lot of. The first example sentence is "I made a lot of mistakes in my test" in which she says that it was possible to exchange for "I made many mistakes in my test." In addition, she says it is more common and more informal to say "a lot of". Carina also presents the form "lots of" and the example sentence "There are lots of people here" and says that this form is also informal and it is more common to appear in affirmative sentences rather than "much" and "many", which corresponds to the use of the three dimensions (Larsen-Freeman et al., 2016). Furthermore, the teacher says that "much" and "many" are more common to appear in questions and negative sentences. She finishes the grammar explanation with the example "How much is it" and says that it is used to ask for the price of something.

Based on this video, it seems that Carina opted for a deductive approach. She first explains the grammar and then gives the example afterwards. She talks about the form generically by giving its definition in oral form. The examples sentences were not authentic and there was not any contextualization before approaching the grammar topic. The meaning she provided was a translation of every example sentence she used. For the use of the grammar, she mentioned "a lot of" and "lots of" but she did not give a satisfying explanation of the difference between the two; she only mentioned that the second one is even more informal.

For the technology, the use of animations to illustrate the counting of nouns might be good for students who are able to understand a concept better with a visual aid. Furthermore, the scene of a TV show showing a person alone right after a sentence that says, "I don't have friends" was a good idea to elicit the example, besides being a good source of authentic material (Bernardo, 2006). The use of captions with a different color on the grammar topic is also interesting to make student visualize the concept and focus on it. There was no interaction with students, but it is worth to mention that on the day the video was uploaded, she posted a quiz about the quantifiers on her Instagram stories. However, it only stays for $24 \mathrm{~h}$ so it was not possible to check the exercises.

Much and Many não erre mais!| \#VideoTodoDia by Inglês Compatilhado

The teacher did not specifically clarify the reason for her video. She said that she struggled with memorizing the use of "much" and "many" and 
that the she needed a "trick" in order to apply the correct quantifier. After that, she said that "much" contains the letter " $u$ " of uncountable, and that every time she would use a quantifier she would remember that letter. For "many" she said that it was used with the "rest", with the countable, although she did not elaborate on its meaning. As the video was short, there was no review or conclusion on the topic.

Thus, it is dubious if there was any approach since she did not explain the difference between countable and uncountable nouns. Thornbury (1999) says that grammar lessons consist of working the grammar a rule, providing examples in which the rule is applied, doing written exercises and, if possible, putting the content in speaking practice. Since there was not interaction with students, it was not possible to consider the grammar video as inductive as well. In fact, this video cannot stand-alone and depends on another one that provides such information. There is another video on the teacher's channel, she gives examples of countable and uncountable nouns, but she does not mention the quantifiers. If a student watched both videos, she or he might have difficulties linking the two ideas together, especially because there is not exposure to examples and illustrations of the two ideas together. The only example provided is on the comment of the channel of this video and consists of two decontextualized sentences: one to illustrate "much" and another to illustrate "many."

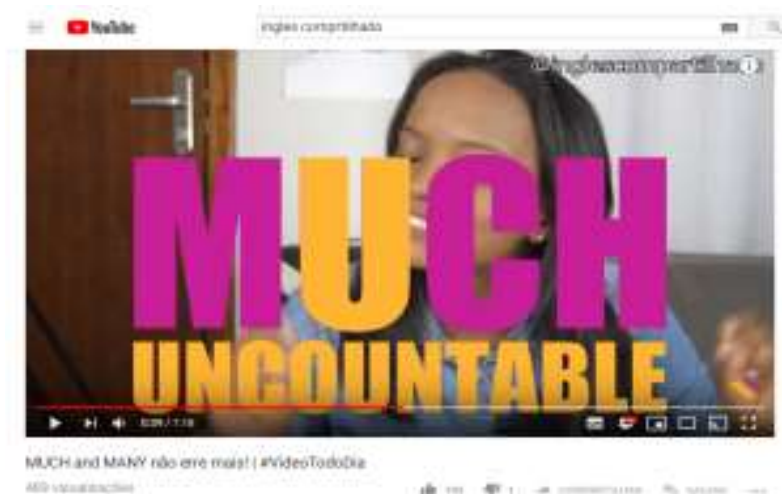

Figure 4. Inglês Compartilhado's video about quantifiers

Regarding technology, the teacher only used the letter " $u$ " in orange color in the word "much", while the rest of the word was in purple. To sum things up, the title of the video might be misleading since there was no approach of meaning, use or form of the grammar topic, which might be the reason students decided to watch it. Furthermore, the approach does not correspond to the deductive or inductive one since both require a deeper contact with the grammar point (Larsen-Freeman et al., 2016; Thornbury, 1999). Finally, the technology was minimum but quite relevant for explanation the teacher provided on the video.

\section{MUCH X MANY: Qual a diferença e como usar? By Mairo Vergara}

Mairo starts the explanation with the quantifier "much": "Think about much as a large amount... like much water... which literally means "muita água". He then gives a similar explanation with "much money" and says that anything that you cannot count goes with much. He orally provides examples of form as "too much" and "how much" and quickly gives their translation in Brazilian Portuguese. $\mathrm{He}$ continues the explanation and provides the context of the importance of drinking water, which comes with the example on the video: "How much water should I drink per day?" Next, he admits that the example sentence "There's too much water in the bucket" does not make much sense, but he uses it to illustrate even so. This whole part of the video corroborates with the deductive approach since most of the contextualization of the grammar is done orally (Thornbury, 1999). Although he claims that thinking about the grammar rules of countable and uncountable nouns confuses people's mind, he clarifies the grammar form of much by saying that you use it with words that you cannot count. Thus, so far, he addresses one of the dimensions: the form (Larsen-Freeman et al., 2016).

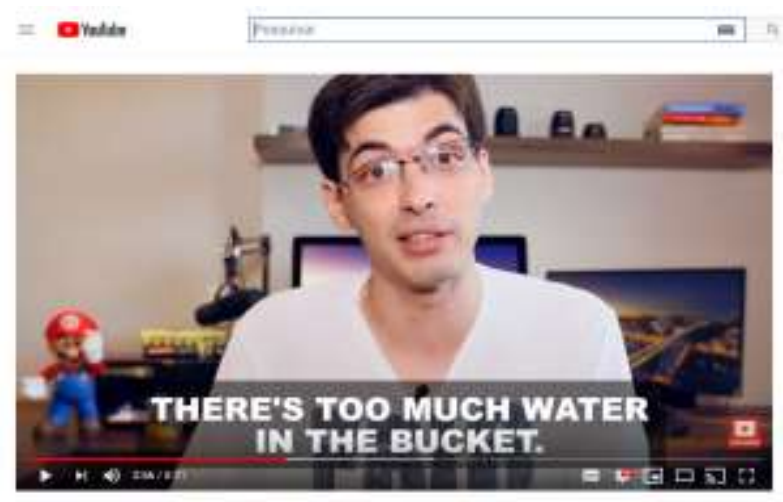

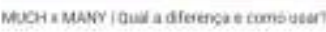

Figure 5. Mairo Vergara's example sentence of much

After that, he starts the explanation of "many". In order to contextualize the first example, he mentions a person that is popular on Facebook and shows the sentence "I have many friends on Facebook." For the meaning of the sentence, he translates it. He also uses the camera 
that is recording the video, his computers and his table to illustrate the phrases "Many cameras", "Many computers" and "Many tables" and says that you use many with things that you can count. Moreover, he approaches the question form with the example "How many friends do you have on Facebook?" and addresses that like "too much", it is possible to use "too many", even though he does not explain its use and meaning.

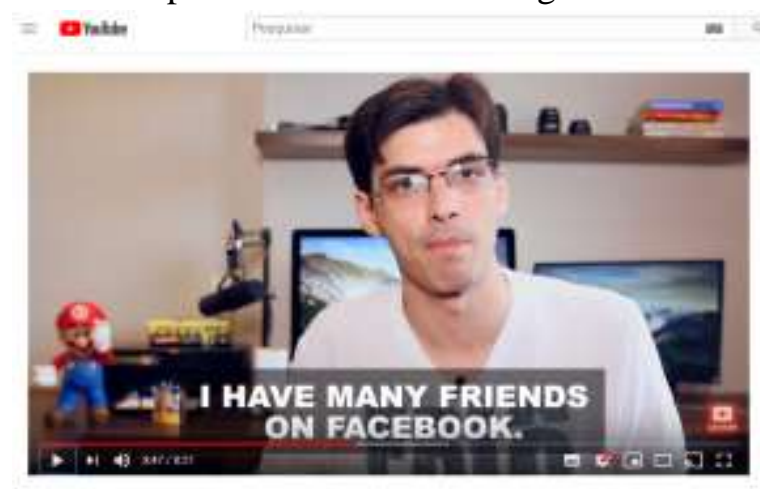

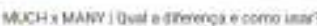

Figure 6. Mairo Vergara's example sentence with many

He reviews the content again by saying that "much" is for things that you cannot count and "many" is for things that you can count. There is no mention of the form of nouns (singular and plural) which is an important part of the grammar if you follow the three dimensions by LarsenFreeman et al. (2016). There are also exercises, but there is a link to his website with extra explanation and download of a pdf and audio file. Although he did not explain the form of the quantifiers deeply, it is undeniable that the teacher used the deductive approach to explain the quantifiers, since he first mentions the rule and provides an example sentence (Thornbury, 1999). In the end of the video, Mairo says that if the students expose to the language naturally, they will learn the difference between "much" and "many" better. He then claims that his video is to enhance their learning by giving a notion of the two quantifiers.

\section{Videos about phrasal verbs}

Phrasal verbs que você PRECISA saber em Inglês! By English In Brazil

Carina defines phrasal verb as a combination of a verb and a preposition; a verb and an adverb; and a verb, an adverb and a preposition. This was the only approach to the form of phrasal verbs during the video. She then explains that she decided to talk about 10 phrasal verbs that she finds useful and common.
In general, the meaning the teacher gives consists of a Brazilian Portuguese word equivalent to the phrasal verb and a translation of the example sentences. The only phrasal verb for which she gives the meaning only in English was "carry on". A reason for that may be that "to continue" is similar to Brazilian Portuguese, so it is not necessary to translate it. As LarsenFreeman (1991) considers meaning as the denotation of a grammatical aspect, we can consider the meaning Carina provides as enough for students' understanding. She also addresses synonyms for the phrasal verbs in English, but she does not explain the difference between them. For the phrasal verbs, "come up with", "find out", "get away", "go on" and "make up", she provides more than one meaning. Since the number of phrasal verbs is quite lengthy, Table 1 shows all the phrasal verbs.

Table 1. English in Brazil example sentences of phrasal verbs

\begin{tabular}{|c|c|c|}
\hline $\begin{array}{c}\text { Phrasal } \\
\text { verb }\end{array}$ & Meaning & Example sentence(s) \\
\hline Call off & To cancel & $\begin{array}{l}\text { The strike has been } \\
\text { called off. } \\
\text { She called off the } \\
\text { wedding. }\end{array}$ \\
\hline Carry on & $\begin{array}{l}\text { To } \\
\text { continue }\end{array}$ & $\begin{array}{l}\text { Carry on! You're doing } \\
\text { fine! } \\
\text { I gotta carry on my work. }\end{array}$ \\
\hline $\begin{array}{l}\text { Come up } \\
\text { with }\end{array}$ & $\begin{array}{l}\text { To } \\
\text { propose, to } \\
\text { contribute, } \\
\text { to emerge, } \\
\text { and to give } \\
\text { an idea. }\end{array}$ & $\begin{array}{l}\text { He finally came up with } \\
\text { a great idea. } \\
\text { Don't worry! I'll come } \\
\text { up with a solution. }\end{array}$ \\
\hline Find out & $\begin{array}{l}\text { To find, to } \\
\text { discover }\end{array}$ & $\begin{array}{l}\text { That's what I'm trying to } \\
\text { find out. } \\
\text { We may never find out } \\
\text { the truth. } \\
\text { The police is going to } \\
\text { find out who killed her. } \\
\text { I don't want anybody } \\
\text { else to find out about it. }\end{array}$ \\
\hline $\begin{array}{l}\text { Get away } \\
\text { (with) }\end{array}$ & $\begin{array}{l}\text { To escape, } \\
\text { to run }\end{array}$ & $\begin{array}{l}\text { I can't wait to get away } \\
\text { from this town. } \\
\text { The thieves managed to } \\
\text { get away. } \\
\text { How to get away with } \\
\text { murder. }\end{array}$ \\
\hline Go on & $\begin{array}{l}\text { To } \\
\text { continue, } \\
\text { to happen }\end{array}$ & $\begin{array}{l}\text { We can't go on like this } \\
\text { anymore. } \\
\text { Go on, go on, ... just } \\
\text { walk away. } \\
\text { What's going on? } \\
\text { I wonder what's going } \\
\text { on next door. }\end{array}$ \\
\hline
\end{tabular}


ENGLISH REVIEW: Journal of English Education Volume 8, Issue 1, December 2019

Look for To search I'm looking for my keys. (for) I'm searching for something on Google.

Make up To invent, He made up a very to make interesting story. piece with Why don't you make up? someone She made up with Tom.

Run out of To be out They're running out of of money.

We've run out of sugar.

Watch out To pay attention hit the car!

You'd better watch out.

Out of the ten phrasal verbs of the video, Carina only provides the use of "look for". She says that it is possible to use "search for" as well. However, she does not clearly explain the appropriate situation in which the speaker should use it, which does not match Larsen-Freeman's (1991) view about the approach of use. In fact, she said, "I'm searching for something on Google" and moved on to the next phrasal verb.

With reference to the description of the teacher's explanation, it is conclusive that her approach was deductive, since it corroborates with Thornbury (1999); she firstly introduced the topic of the video and then she explained the content, and finally provided examples. The examples were not in context excepted for the phrasal verb "watch out", where pictures of sign appear to illustrate that the verb means caution. In fact, it was the only extra technology appeared on the video.

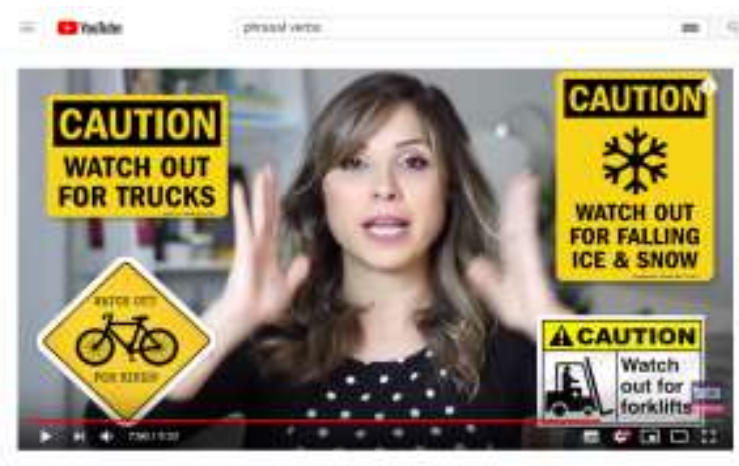

Figure 7. Pictures of signs to illustrate the phrasal verb "Watch out"

\section{Phrasal verbs I always use by Inglês Compartilhado}

The video is completely in English and Tainá provides the form of phrasal verbs: two or three words that together have one meaning. Furthermore, she specifies that they consist of a verb and an adverb or a verb and a preposition. We can say that this is a good attempt to 'form' according to Larsen-Freeman's et al. three

p-ISSN 2301-7554, e-ISSN 2541-3643

https://journal.uniku.ac.id/index.php/ERJEE

dimensions (2016). Tainá also mentions that the phrasal verbs can be separated. Although she acknowledges there are grammar rules regarding it (separable and inseparable phrasal verbs), she does not explain them. She believes students do not need to think about them since they probably learn phrasal verbs by watching movies or reading articles. Contrary to that, she says that if the words "something", "someone" or "somebody" appear, it means that the phrasal verbs are separable. Such explanation might not be enough for students, though. As Thornbury (1999) claims, apart from being a set of rules and a question of correctness, grammar is also a tool for conveying meaning and this meaning is important when the context information is not explicit.

She addressed the meaning by providing its meaning with an alternative word. Thus, she taught a formal word that is the equivalent to the phrasal verb. An example was the phrasal verbs "get back" and "go back" that mean "to return"; but "go back" specifically means "to return to a place." As for the use, she said it was the students' choice to use one or another. Hence, she misses the opportunity to clarify the difference in formality between the phrasal verbs and words that derive from Latin.

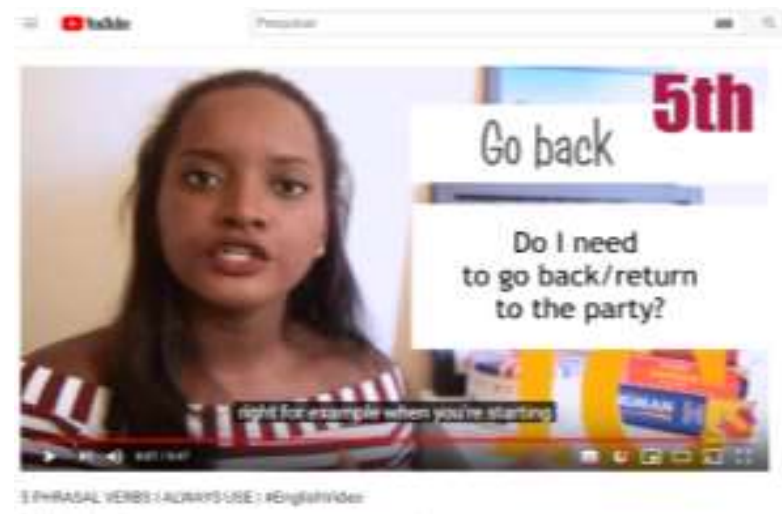

Figure 8. Inglês Compartilhado's example of phrasal verbs' meaning

Regarding technology, the video has subtitles in English and captions to illustrate the grammar. However, the subtitles were delayed and sometimes they did not correspond with what the teacher was saying. In particular, the teacher says, "to get back means to return" but the subtitles showed "right gasps back many years to regard so". For a video that did not specify the target level of English, it probably misled many viewers, which might make understanding it more difficult. 
The teacher mentioned the phrasal verb, provided its meaning and example sentences. The examples were not in context except when she uses "find out" since she always loses things. She repeats the examples sentences and the phrasal verbs individually, but they are not authentic. Regarding content review, the teacher did not provide any. The lesson was deductive, although there were not exercises. Table 1 presents the examples sentences appeared on the video.

Table 2. Inglês Compartilhado's example sentences of phrasal verbs

\begin{tabular}{|c|c|c|}
\hline $\begin{array}{c}\text { Phrasal } \\
\text { verb }\end{array}$ & Meaning & Example Sentence \\
\hline $\begin{array}{l}\text { Put up } \\
\text { with }\end{array}$ & To tolerate & $\begin{array}{l}\text { Why do you still put up } \\
\text { with/tolerate this } \\
\text { situation? }\end{array}$ \\
\hline $\begin{array}{l}\text { Call sth } \\
\text { off }\end{array}$ & To cancel & $\begin{array}{l}\text { I'm sorry but I have to } \\
\text { call off/cancel } \\
\text { the party. } \\
\text { I'm sorry but I have to } \\
\text { call the party off. }\end{array}$ \\
\hline $\begin{array}{l}\text { Fall } \\
\text { down }\end{array}$ & $\begin{array}{l}\text { Fall to the } \\
\text { ground. }\end{array}$ & $\begin{array}{l}\text { Hey! Caution! } \\
\text { It's gonna fall down/ fall } \\
\text { to the ground again. }\end{array}$ \\
\hline $\begin{array}{l}\text { Find sth } \\
\text { out }\end{array}$ & $\begin{array}{l}\text { To } \\
\text { discover }\end{array}$ & $\begin{array}{l}\text { I found it out yesterday } \\
\text { morning. } \\
\text { I need to found } \\
\text { out/discover where my } \\
\text { keys are. } \\
\text { I found it out/ discovered } \\
\text { yesterday morning. }\end{array}$ \\
\hline Get back & To return & $\begin{array}{l}\text { Do I need to get } \\
\text { back/return? }\end{array}$ \\
\hline Go back & $\begin{array}{l}\text { To return } \\
\text { to another } \\
\text { place }\end{array}$ & $\begin{array}{l}\text { Do I need to go } \\
\text { back/return to the party? }\end{array}$ \\
\hline
\end{tabular}

Mini-aula de inglês | phrasal verbs \#001 |fall down by Mairo Vergara

Mairo recalls that a verb represents an action (walk, talk, write, run) and in English, it is possible to have until three words together to represent an action, but two words is more common. Grammatically, that combination of words forms the phrasal verbs (he selects "phrasal verbs" on the Notepad he projects from his computer on the video). That was his approach to the form of the grammar which did not mention what type of words form a phrasal verb. Regarding Larsen-Freemans et al. (2016) view on grammar, this explanation might not be enough for students, since they can imply that any word put together with another word can be considered a phrasal verb.

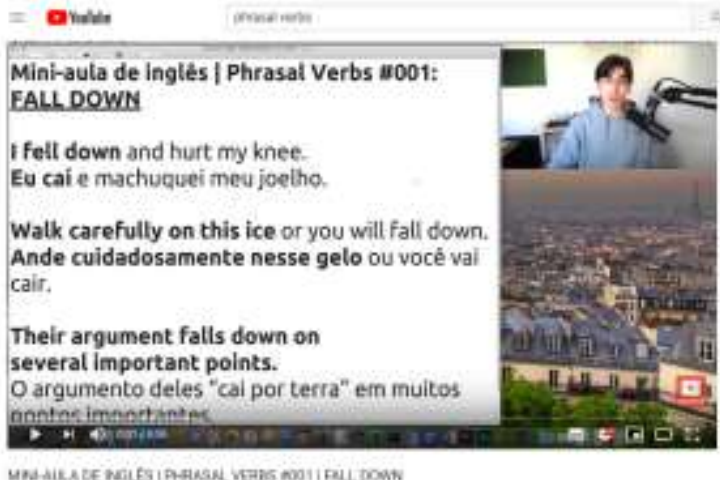

Figure 9. Mairo Vergara's video about phrasal verbs

Then, he says that he is going to start with the phrasal verb "fall down" because it has two different meanings. The first meaning is "to fall to the ground", whereas the second one is similar to the Brazilian Portuguese expression "cair por terra". He exemplifies it by saying that when a theory is no longer able to sustain its thesis, it is possible to say that it fell down. For the use of the phrasal verb, he said that it was possible to use "fall" of "fall down" since both mean the same and did not provide a difference between the two. Overall, he shows two example sentences with their respective translation in his native language to illustrate "fall to the ground" and one example to illustrate something that is not true anymore.

Although his example sentences did not contain a context and were not authentic, the teacher provided translation sentences for them. He used the software Notepad on his computer to select the sentences in real time which permitted the students to focus on what he was saying. Table 3 shows the example sentences of phrasal verbs appeared on the video.

Table 3. Mairo Vergara's example sentences of phrasal verbs

\begin{tabular}{lll}
\hline $\begin{array}{c}\text { Phrasal } \\
\text { verb }\end{array}$ & Meaning & Example sentence \\
\hline $\begin{array}{l}\text { Fell } \\
\text { down }\end{array}$ & $\begin{array}{l}\text { To fall to } \\
\text { the } \\
\text { ground }\end{array}$ & $\begin{array}{l}\text { I feel down and hurt } \\
\text { my knee. } \\
\text { Eu caí e machuquei o } \\
\text { meu joelho. }\end{array}$ \\
Fall & To fall to & Walk carefully on \\
down & the & $\begin{array}{l}\text { this ice or you will } \\
\text { fall down. } \\
\text { ground cuidadosamente } \\
\end{array}$ \\
& & $\begin{array}{l}\text { Andese gelo ou você } \\
\text { vai cair. }\end{array}$
\end{tabular}


ENGLISH REVIEW: Journal of English Education Volume 8, Issue 1, December 2019

$\begin{array}{lll}\text { Falls } & \text { Does not } & \text { Their argument falls } \\ \text { down } & \text { sustain } & \text { down on several } \\ & \text { its claim } & \text { important points. } \\ & & \text { O argumento deles } \\ & & \text { "cai por terra" em } \\ & & \text { muitos pontos } \\ & & \text { importantes. }\end{array}$

\section{CONCLUSION}

Regarding the grammar approach, the deductive one was unanimous among the videos that contained grammar explanations (Inglês Compartilhado's video about quantifiers did not have grammar, only a trick to memorize the use of "much" and "many"). Broadly speaking, the videos about quantifiers and phrasal verbs followed a similar pattern of addressing the grammar topic, mentioning some grammatical form, meaning and use of the grammar and providing example sentences. As for the form, teachers tended to explain the concept of quantifiers and phrasal verbs orally which probably required more cognitive effort from the students. This corroborates with the fact that there were no specific tags for the level of the audience and Carina Fragozo was the only one to mention in the video about quantifiers was for basic levels. Although the form of the grammar topics consisted of affirmative examples, there was a short mention of the question form of quantifiers but the teachers did not provide further explanation on how to construct questions.

The meaning of the grammar on Carina Fragozo and Mairo Vergara's videos did have a translation of the example sentences they provided. Both mentioned that "a lot of" meant "much" and "many", respectively. As for the phrasal verbs, Carina particularly provided many meanings in her native language for "come up with". She also provided two different meanings for "make up". Mairo Vergara did also provide more than one meaning for "fall down". Taina's video resulted in providing formal words that share the meaning of the phrasal verbs since it was entirely in English.

As for the use of the grammar, Carina Fragozo and Mairo Vergara focused on different use for the quantifiers. While Carina said that "a lot of" and "lots of" were an informal way to substitute "much" and "many", Mairo Vergara opted for mentioning that it was also possible to use "too much" with further explanation. He also claimed that it is possible to use the quantifiers to make questions.
p-ISSN 2301-7554, e-ISSN 2541-3643

https://journal.uniku.ac.id/index.php/ERJEE

The approach of use with the phrasal verbs had difference among the teachers. Since Taina's video was in English, she said that it was the student's choice if they wanted to use the phrasal verb or the words that derived from Latin. Mairo Vergara said that students could use the verb "fall" or the phrasal verb "fall down" since both mean the same. He also addressed that it was possible to use "fall down" when someone needed to say that a theory did no longer sustain its claim. Carina only mentioned the use of "look for", in which she claims that it was possible to use "search for" as well, meaning "looking for answers".

Captions were the prevalent technology that teachers used in order to illustrate the three dimensions and Carina was the only one who used a different color to highlight the grammar. Besides the use of captions, other technological tools were part of the teachers' videos. Taina used subtitles in English on her phrasal verbs video, but it presented some delay and its description frequently did not match with her speech which would possibly confuse viewers. Carina used pictures of caution signs to illustrate the phrasal verb "watch out", whereas Mairo Vergara projected the software Notepad from his computer to highlight the example sentences he prepared to address the phrasal verb "fall down". All things considered, although these technologies are not cutting-edge, they are practical, since they are not time-consuming and usually appeared on time of the teacher's explanation.

All in all, in terms of the pedagogical approach, this paper found that the grammar videos, in general, followed a traditional teaching that is similar to what happens in physical classrooms. The main difference regards technology tools. The captions and Notepad that appeared on the videos substitute the markers on the whiteboard or the slide presentation. Furthermore, they are not as time-consuming because they appear at the moment of the teachers' speech.

For further investigation and future studies, it is important to evaluate the student's comprehension of the LLVs through exercises. What is more, it is important to interview the teachers in order to understand their choices about their approaches and beliefs in teaching. This information is vital to investigate if there should be some type of modification regarding teaching practice for online videos and if it is 
necessary to innovate in terms of pedagogical approach and technology.

\section{REFERENCES}

Alhamami, M. (2013). Observation of YouTube language learning videos (YouTube LLVS). Teaching English with Technology, 13(3), 3-17, 2013.

Bernardo, S. A. (2006). The use of authentic materials in the teaching of reading. Reading Matrix: An International Online Journal, 6(2).

English in Brazil by Carina Fragozo. 10 Phrasal Verbs que você PRECISA saber em inglês | English in Brazil. Retrieved on Oct. $6^{\text {th }}$, 2018 from https://www.youtube.com/watch?v=9r7Jba1L1 $\mathrm{U} 4 /$.

English in Brazil by Carina Fragozo. Much/many/a lot of: Aprenda a regra! (countable/uncountable nouns). Retrieved on Oct. 6 ${ }^{\text {th }}, 2018$ from https://www.youtube.com/watch?v=Ff4pmSCf $5 \mathrm{sM} /$.

English in Brazil by Carina Fragozo. Youtube channel. Retrieved on Oct. $3^{\text {rd }}, 2018$ from https://www.youtube.com/user/carinafragozo/.

Gerstein, J. (2014). Moving from education 1.0 through education 2.0 towards education 3.0. In L. M. Blaschke, C. Kenyon, \& S. Hase (orgs.), Experiences in self-determined learning. United States: Create Space Independent Publishing Platform. Retrieved on Nov. 3rd, 2018 from https://scholarworks.boisestate.edu/edtech_facp ubs/104/.

Inglês Compartilhado. 5 Phrasal verbs I always use | \#EnglishVideo. Retrieved on Oct. 20 2018 from

https://www.youtube.com/watch?v=tZC2Iwm AYEU/.

Inglês Compartilhado. Much and Many não erre mais! \#VideoTodoDia. Retrieved on Oct. $15^{\text {th }}, 2018$ from

https://www.youtube.com/watch?v=aYk4BEg9 $1 \mathrm{Y} 4 /$.

Inglês Compartilhado. Youtube channel. Retrieved on $\begin{array}{llll}\text { Oct. } & 3^{\text {rd }}, & 2018 & \text { from }\end{array}$ https://www.youtube.com/channel/UCYlPC7B 0QJV4HiVqSfs-h5Q/featured/.

Kelsen, B. (2009). Teaching EFL to the iGeneration: A survey of using YouTube as supplementary material with college EFL students in Taiwan. Call-EJ Online, 10(2), 1-18.

Larsen-Freeman, D. (1991). Teaching grammar. Teaching English as a Second or Foreign Language, 2, 251-266.

Larsen-Freeman, D., et al. (2016). The grammar book: Form, meaning, and use for English language teachers $\left(3^{\text {rd }}\right.$ ed.). Massachusetts: National Geographic Learning, Heinle Cengage Learning.
Levy, M. (1997). Computer-assisted language learning: Context and conceptualization. Oxford: Clarendon Press.

Lyrics Training. Retrieved on Sept. $28^{\text {th }}, 2018$ from https://lyricstraining.com/.

Mairo Vergara. Mini-aula de inglês | phrasal verbs $\# 001 \mid$ fall down. Retrieved on October $6^{\text {th }}$, 2018 from https://www.youtube.com/watch?v=i8sEInbLs $2 \mathrm{~g} /$.

Mairo Vergara. MUCH $x$ MANY $\mid$ Qual a diferença e como usar? Retrieved on Oct. $6^{\text {th }}, 2018$ from https://www.youtube.com/watch?v=M8CYBon $\mathrm{p} 3 \mathrm{Sc} /$.

Mairo Vergara. Youtube channel. Retrieved on Oct. $3^{\text {rd }}, \quad 2018$ from https://www.youtube.com/user/MairoVergara/.

Mayora, C A. (2009). Using YouTube to encourage authentic writing in EFL classrooms. TESL Reporter, 42(1), 1-12.

Oliveira, A. J., \& Viggiano, G. (2018). Youtubers democratizam o acesso à educação: conheça principais canais. Retrieved on Sept. $26^{\text {th }}, 2018$ from

https://revistagalileu.globo.com/Revista/noticia /2018/03/youtubers-democratizam-o-acessoeducacao-conheca-principais-canais.html/.

Scrivener, J. (2010). Teaching English grammar: What to teach and how to teach it. Oxford: Macmillan.

Silviyanti, T. M. (2014). Looking into EFL students' perceptions in listening by using English movie videos on YouTube. Studies in English Language and Education, 1(1), 42-58.

Ted: Ideas Worth Spreading. Ted talks. Retrieved on September $28^{\text {th }}, \quad 2018$ from https://www.ted.com/.

Teded: Lessons Worth Sharing. Lessons. Retrieved on $\begin{array}{llll}\text { Sept. } & 28^{\text {th }}, & 2018 & \text { from }\end{array}$ https://ed.ted.com/lessons.

Thornbury, S. (1999). How to teach grammar. Harlow: Longman.

Watkins, J., \& Wilkins, M. (2013). Using YouTube in the EFL classroom. Language Education in Asia, 2(1), 113-119. Retrieved on Sept. $28^{\text {th }}$, 2018 from https://pdfs.semanticscholar.org/9367/8536235 9166c33467e3e48d0242188cfe31d.pdf/.

Youglish. (2018). Retrieved on Sept. $28^{\text {th }}$, 2018 from https://youglish.com/. 